\title{
A rare indication for surgical treatment in mycosis fungoides
}

\section{Rzadkie wskazanie do leczenia chirurgicznego w ziarniniaku grzybiastym}

\author{
Michał Bąk $k^{1,2}$, Sławomir Cieśla', Dawid Murawa',2 \\ 'Clinical Department of General and Oncological Surgery, University Hospital, Zielona Gora, Poland \\ 2Department of Surgery and Oncology, Faculty of Medicine and Health Sciences, University of Zielona Gora, Poland \\ 'Oddział Kliniczny Chirurgii Ogólnej i Onkologicznej, Szpital Uniwersytecki w Zielonej Górze, Polska \\ 2Katedra Chirurgii i Onkologii, Wydział Lekarski i Nauk o Zdrowiu, Uniwersytet Zielonogórski, Polska \\ Dermatol Rev/Przegl Dermatol 2021, 108, 232-235 \\ DOI: https://doi.org//0.5 I |4/dr.2021.108606
}

We present an unusual, surgical method of treatment of a locally advanced mycosis in an adult man treated at the Department of General and Oncological Surgery of the University Hospital in Zielona Gora.

Mycosis fungoides is a chronic malignant skin cancer from T cells of the lymphatic system. The essence of the disease is the uncontrolled proliferation of $\mathrm{T}$ cells localized in the skin (cutaneous T-cell lymphoma - CTCL).

The incidence of the disease is estimated at 0.29 cases per 100 thousand. population. It affects men about twice as often $[1,2]$. The etiology of the disease is not known exactly [3, 4].

On March 26, 2020, we admitted a 79-year-old man referred from the Department of Hematology of the University of Life Sciences in Zielona Gora due to a huge inflammatory infiltrate with ulceration of the left thigh. The patient was admitted years ago with a diagnosis of mycosis fungoides of the left thigh. Apart from the extensive, disintegrating ulceration of the posterior part of the right thigh, no nodal or organ changes were found.

The first erythematous lesions on the skin appeared in August 2011. The patient was treated in the Dermatological Outpatient Department with methotrexate $20 \mathrm{mg} /$ week and methylprednisolone $12 \mathrm{mg} /$ day. In April 2012, there was a significant deterioration of the local skin condition in the form of numerous erythematous, erythematous infiltrative and single nodular eruptions scattered over the surface of entire body. Diagnostic procedures were performed in the Department of Dermatology, Venereology and Allergology, Clinical Hospital No. 1 in Wroclaw. The diagnosis was established and the treatment of skin lesions was introduced. For several days of hospitalization, the patient was observed to have a large inflammatory infiltrate with left thigh edema accompanied by fever up to $38.5^{\circ} \mathrm{C}$. Histo-
Przedstawiamy nietypowy, chirurgiczny sposób zaopatrzenia miejscowo zaawansowanego ziarniniaka grzybiastego u mężczyzny leczonego w Klinice Chirurgii Ogólnej i Onkologicznej Szpitala Uniwersyteckiego w Zielonej Górze.

Ziarniniak grzybiasty jest przewlekłym złośliwym nowotworem skóry wywodzącym się z komórek T układu chłonnego. Istotą choroby jest niekontrolowany rozrost limfocytów T zlokalizowanych w skórze (cutaneous T-cell lymphoma - CTCL).

Częstość występowania choroby szacuje się na 0,29/100 000 ludności. Około dwukrotnie częściej dotyczy mężczyzn $[1,2]$. Etiologia schorzenia nie jest dokładnie znana $[3,4]$.

W dniu 26 marca 2020 roku przyjęliśmy 79-letniego mężczyznę skierowanego z Klinicznego Oddziału Hematologii Szpitala Uniwersyteckiego w Zielonej Górze z powodu olbrzymiego nacieku zapalnego z owrzodzeniem lewego uda. Chory przyjęty z ustalonym przed laty rozpoznaniem ziarniniaka grzybiastego w tej lokalizacji. Oprócz rozległego, rozpadającego się owrzodzenia tylnej części lewego uda nie stwierdzono dodatkowo zmian węzłowych i narządowych.

Pierwsze zmiany na skórze $\mathrm{w}$ postaci plam rumieniowych wystąpiły w sierpniu 2011 roku. Pacjent leczony $\mathrm{w}$ ambulatorium dermatologicznym przyjmował metotreksat $\mathrm{w}$ dawce $20 \mathrm{mg}$ tygodniowo oraz metyloprednizolon w dawce $12 \mathrm{mg} /$ dobę. W kwietniu 2012 roku doszło do znacznego pogorszenia stanu miejscowego skóry w postaci licznych zmian rumieniowych, rumieniowo-naciekowych oraz pojedynczych guzkowych rozsianych na całej skórze. W Klinice Dermatologii, Wenerologii i Alergologii Szpitala Klinicznego nr 1 we Wrocławiu przeprowadzono diagnostykę, ustalono rozpoznanie i włączono leczenie zmian skórnych. Przez kilka dni hospitalizacji u chorego obserwowano duży naciek zapalny z obrzękiem uda lewego z towa- 
pathological examination confirmed the diagnosis: "Mycosis fungoides with large cell transformation". In additional tests, significant leukocytosis up to $22,000 / \mu 1$, increased inflammatory parameters (CRP - $77.4 \mathrm{mg} / \mathrm{l}$ ) and increased levels of tumor markers Ca 125 II (280.4 U/ml), and Ca 15-3 (91.6 U/ml) were observed. Imaging excluded changes in lymph nodes and organs beyond the skin. The outpatient chemotherapy cycle was proposed according to the CHOP (cyclophosphamide, doxorubicin, vincristine, prednisolone) regimen. During subsequent exacerbations of the disease, interferon was also included (peginterferon alfa-2a $90 \mu \mathrm{g}$, once a week). Since the diagnosis, PUVA irradiation has been used 2-4 times a week with intervals during remission.

In the $8^{\text {th }}$ year of his illness, the patient was admitted to the Department of Hematology of the University Hospital in Zielona Gora due to recurrence of the disease on the back of the left thigh, with a massive, oozing ulcer, limiting the patient's functioning. Bone marrow was collected for histopathological examination. The histopathological study dated on April 3, 2020 stated: CD3+ about 4\%,CD4+ about 5-10\%, CD5+ only single cells, CD $8+$ about $5 \%$. This presentation could suggest a slight (CD4+) marrow infiltration by mycosis fungoides. Because of the size and depth of the inflammatory infiltrate with necrotic ulcerations, a decision was made to use surgical treatment.

On March 27, 2020, a radical surgical excision of the thigh lesion was performed, maintaining a mini-

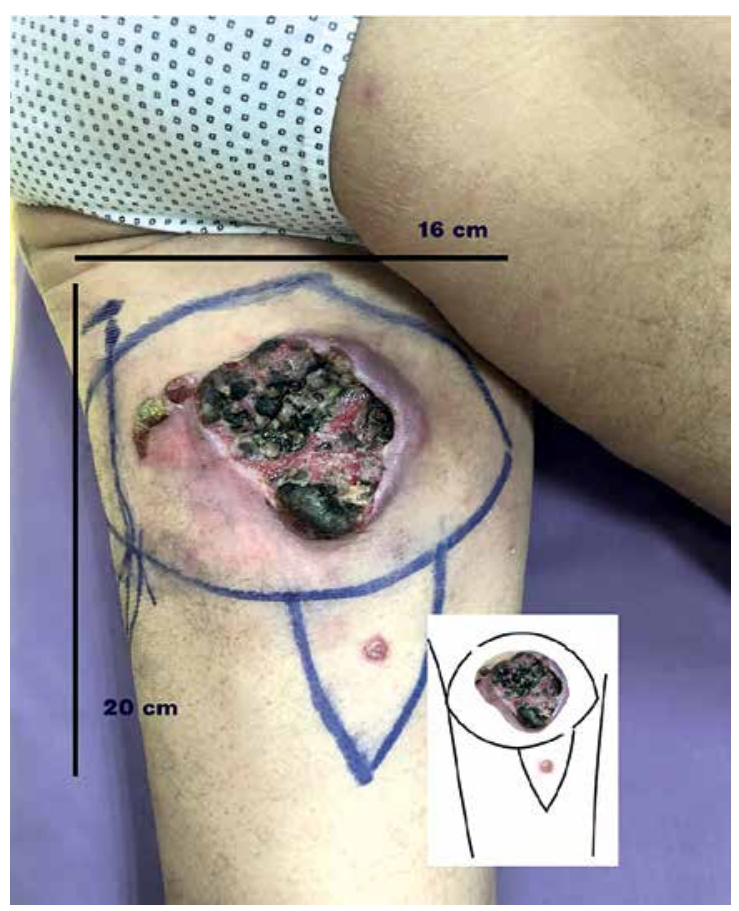

Figure I. Inflammatory lesion with an ulceration on the left thigh Rycina I. Zmiana zapalna z owrzodzeniem uda lewego rzyszącą gorączką do $38,5^{\circ} \mathrm{C}$. Badanie histologiczne potwierdziło rozpoznanie: mycosis fungoides with large cell transformation. W badaniach dodatkowych obserwowano znaczną leukocytozę do 22 tys./ $\mu \mathrm{l}$, podwyższone parametry stanu zapalnego (CRP - 77,4 mg/l) oraz podwyższone poziomy markerów nowotworowych Ca 125 II (280,4 U/ml) oraz Ca 15-3 (91,6 U/ml). W badaniach obrazowych wykluczono zmiany w węzłach chłonnych i narządach poza skórą. Zaproponowano cykl chemioterapii w trybie ambulatoryjnym według schematu CHOP (cyklofosfamid, doksorubicyna, winkrystyna, prednizolon). Podczas kolejnych zaostrzeń choroby włączono także interferon (peginterferon alfa-2a $90 \mu \mathrm{g} 1$ raz w tygodniu). Od czasu rozpoznania stosowano też naświetlania PUVA 2-4 razy w tygodniu z przerwami w czasie remisji.

W 8. roku trwania choroby pacjent został przyjęty na Kliniczny Oddział Hematologii Szpitala Uniwersyteckiego w Zielonej Górze z powodu wznowy choroby - na tylnej części uda lewego z masywnym, sączącym owrzodzeniem ograniczającym sprawne funkcjonowanie. Pobrano szpik do badania histologicznego. Wynik otrzymano 3 kwietnia 2020 roku - CD3+ ok. 4\%, CD4+ ok. 5-10\%, CD5+ tylko pojedyncze komórki, CD8+ ok. 5\%. Obraz mógł sugerować niewielkie (CD4+) nacieczenie szpiku przez ziarniniaka grzybiastego. Ze względu na wielkość, głębokość nacieku zapalnego z owrzodzeniem z ogniskami martwicy zdecydowano o zastosowaniu leczenia chirurgicznego.

27 marca 2020 roku wykonano radykalne wycięcie chirurgiczne zmiany uda, zachowując minimalny

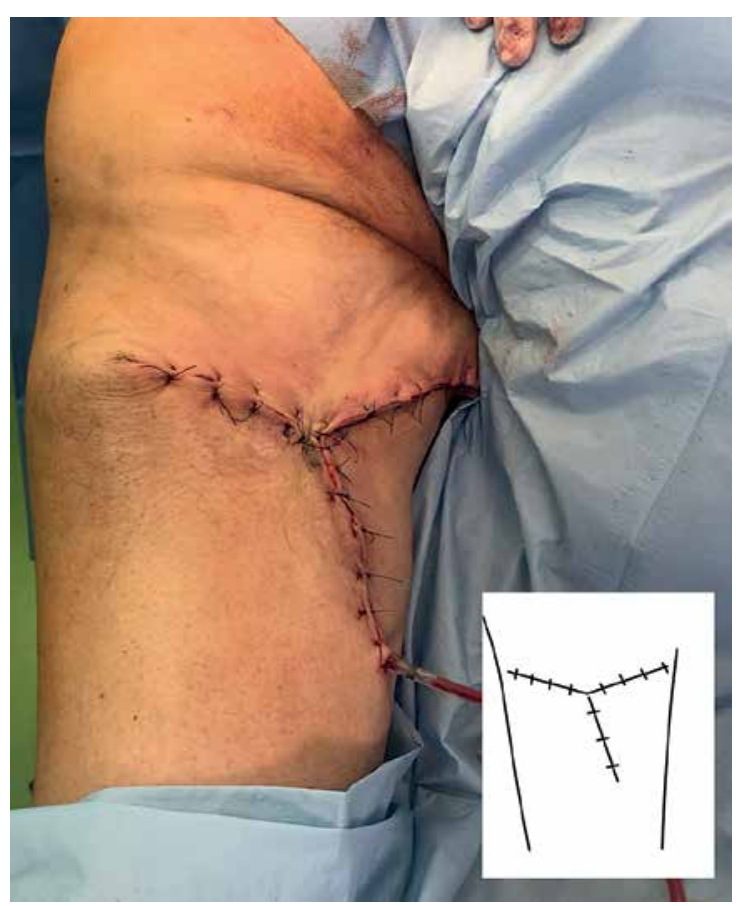

Figure 2. Condition after surgery

Rycina 2. Stan po leczeniu operacyjnym 


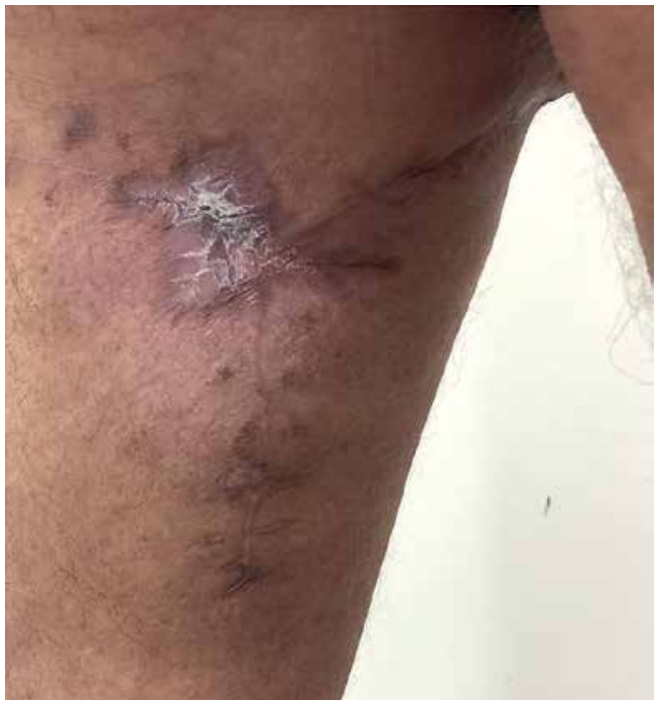

mum $1 \mathrm{~cm}$ margin of healthy tissues. The size of the excised tissue was $16 \times 14 \mathrm{~cm}$. At the same time, the defect was surgically treated with skin and subcutaneous flaps moved from the area of the lesion (fig. 1, 2).

On the third day after the surgery, in good general and local condition, the patient was discharged home, with the recommendation of wound control in outpatient setting, and informed about the need for further dermatological treatment. Surgical control carried out 6 and 12 months after the operation showed good, complete healing of wounds, with linear scars that did not limit the range of motion and free functioning (fig. 3).

After the surgical treatment, the patient remained under constant specialist dermatological supervision. He was treated with methotrexate $10 \mathrm{mg} / 0.2 \mathrm{ml}$ subcutaneously once a week and folic acid (Actifolin $2 \mathrm{mg}$ tablets once a day).

Treatment of mycosis fungoides, both local and systemic, is chronic, symptomatic, and most often performed on an outpatient basis [5].

In limited, single foci of mycosis fungoides, local management can be limited to radiotherapy, local application of glucocorticosteroids or, much less frequently, surgical excision. Lambert et al. described radical surgical removal of the lesion with a $0.5 \mathrm{~cm}$ margin followed by photochemical irradiation with PUVA [6]. Surgical treatment may be complemented by radiotherapy, photodynamic therapy or a $\mathrm{CO}_{2}$ laser. The advantage of the surgical procedure is the possibility of a single, high dose radiotherapy (700800 cGy) in the event of recurrence.

The effectiveness of a single high dose was confirmed by Thomas et al., obtaining $94 \%$ positive responses after 41 months of follow-up [7]. McEvenue et al. described an effective method of surgical treatment of large ulceration of withers of the thumb with a skin graft from the forearm [8]. Brooker and Malata
Figure 3. Control 6 months after surgery

Rycina 3. Kontrola po 6 miesiącach po operacji

1-centymetrowy margines zdrowych tkanek. Wielkość usuniętej w obrębie uda tkanki wynosiła $16 \times 14 \mathrm{~cm}$. Jednocześnie zaopatrzono chirurgicznie ubytek płatami skórno-podskórnymi przesuniętymi z okolicy zmiany (ryc. 1, 2)

W trzeciej dobie po operacji w stanie ogólnym i miejscowym dobrym pacjent został wypisany do domu z zaleceniem ambulatoryjnej kontroli rany i koniecznością dalszego leczenia dermatologicznego. Kontrola chirurgiczna przeprowadzona po 6 i 12 miesiącach od zabiegu wykazała dobre, całkowite wygojenie ran z linijnymi bliznami nieograniczającymi zakresu ruchów i swobodnego funkcjonowania (ryc. 3).

Po leczeniu chirurgicznym chory był pod stałą, specjalistyczną kontrolą dermatologiczną. Leczony metotreksatem w dawce $10 \mathrm{mg} / 0,2 \mathrm{ml}$ podskórnie raz w tygodniu i kwasem foliowym (Actifolin $2 \mathrm{mg}$ tabletki 1 raz dziennie).

Leczenie w ziarniniaku grzybiastym, zarówno miejscowe, jak ogólne, ma charakter przewlekły, objawowy i najczęściej prowadzone jest ambulatoryjnie [5].

W ograniczonych, pojedynczych ogniskach ziarniniaka grzybiastego można zastosować wyłącznie postępowanie miejscowe: radioterapię, miejscową aplikację glikokortykosteroidów lub znacznie rzadziej wycięcie chirurgiczne zmiany. Lambert i wsp. opisali radykalne usunięcie chirurgiczne zmiany z marginesem 0,5-centymetrowym i następczym naświetlaniem fotochemicznym PUVA [6]. Uzupełnieniem leczenia chirurgicznego może być radioterapia, terapia fotodynamiczna lub laser $\mathrm{CO}_{2}$. Zaletą postępowania chirurgicznego jest możliwość $\mathrm{w}$ razie nawrotu zastosowania jednorazowej, wysokiej dawki radioterapii (700-800 cGy).

Skuteczność jednorazowej wysokiej dawki potwierdzili Thomas i wsp., uzyskując $94 \%$ pozytywnych odpowiedzi po 41 miesiącach obserwacji [7]. McEvenue 
proposed radical surgical removal of mycosis fungoides with simultaneous mastopexy in the case of a chronically persistent local lesion in the area of the areola of one breast [9].

Reports of early, sudden relapses of the local disease after surgical removal of the lesion require great caution in undertaking surgical treatment attempts.

\section{CONFLICT OF INTEREST}

The authors declare no conflict of interest. i wsp. opisali skuteczny sposób chirurgicznego leczenia dużego owrzodzenia kłębu kciuka z przeszczepem uszypułowanym skóry z przedramienia [8]. Brooker i Malata zaproponowali w przypadku przewlekle utrzymującej się zmiany miejscowej w okolicy otoczki jednej piersi radykalne chirurgiczne usunięcie ziarniniaka grzybiastego z jednoczesną mastopeksją [9].

Dużą ostrożność w podejmowaniu prób leczenia chirurgicznego nakazują doniesienia o wczesnych, gwałtownych nawrotach miejscowych choroby po usunięciu chirurgicznym guza.

\section{KONFLIKT INTERESÓW}

Autorzy nie zgłaszają konfliktu interesów.

\section{References}

\section{Piśmiennictwo}

1. Sokołowska-Wojdyło M., Maj J., Robak E., Placek W., Wojas-Pelc A., Jankowska-Konsur A., et al.: Primary cutaneous lymphomas - diagnostic and therapeutic guidelines of the Polish Dermatological Society. Dermatol Rev 2017, 104, 243-268.

2. Kempf W., Mitteldorf C.: Cutaneous T-cell lymphomas - an update 2021. Hematol Oncol 2021, 39 Suppl 1, 46-51.

3. D'Incan M., Antoniotti O., Gasmi M., Fonck Y., Chassagne J., Desgranges C., et al.: HTLV-I-associated lymphoma presenting as mycosis fungoides in an HTLV-I non-endemic area: a viro-molecular study. Br J Dermatol 1995, 132, 983-988.

4. Beyer M., Möbs M., Humme D., Sterry W.: Pathogenesis of mycosis fungoides. J Dtsch Dermatol Ges 2011, 9, 594-598.

5. Polakiewicz-Gilowska A., Mrochen-Domin I., Nowara E.: Ziarniniak grzybiasty - opis przypadku i przegląd piśmiennictwa. Onkol Prakt Klin 2010, 6, 195-201.

6. Lambert W.C., Cohen P.J., Schwartz R.A.: Surgical management of mycosis fungoides. Case Rep J Med 1997, 28, 211-222.

7. Thomas T.O., Agrawal P., Guitart J., Rosen S.T., Rademaker A.W., Querfeld C., et al.: Outcome of patients treated with a single-fraction dose of palliative radiation for cutaneous T-cell lymphoma. Int J Radiat Oncol Biol Phys 2013, 85, 747-753.

8. McEvenue G., Kim A., Binhammer P.: Surgical excision of mycosis fungoides usimg thumb-sparing recomnstruction. Hand 2017, 12, 22-26.

9. Brooker J.E., Malata C.M.: Innovative surgical treatment of persistent unilesional breast mycosis fungoides by mastopexy. J Plast Reconstr Aesthet Surg 2015, 68, 132-134.

Received: 30.11 .2020

Accepted: 7.06 .2021

Otrzymano: 30.11.2020 r.

Zaakceptowano: $7.06 .2021 \mathrm{r}$.

How to cite this article:

Bąk M., Cieśla S., Murawa D.: A rare indication for surgical treatment in mycosis fungoides. Dematol Rev/Przegl Dermatol 2021, 108, 232-235. DOI: https:/ / doi.org/10.5114/dr.2021.108606. 